\title{
What Counts as a Proverb? The Case of NTC's Dictionary of Proverbs and Clichés
}

Is'haaq Akbarian, Department of English Language and Literature, Faculty of Humanities, University of Qom, Iran (i-akbarian@qom.ac.ir)

\begin{abstract}
A dictionary on proverbs should meet its claim in compiling the specific, relevant formulaic entries in order to retrieve the required information as quickly and as successfully as possible. The inconsistency between what such a dictionary claims to include and what it actually includes might stem from not attending to the possible boundaries between the fixed expressions that might as well be considered as guidelines in lexicography. Based on the distinctions between the fixed expressions offered in Gramley and Pätzold (1992) and Simpson (1985), NTC's Dictionary of Proverbs and Clichés (Bertram 1996) was investigated as a sample proverb dictionary available, especially useful for non-native speakers. It was found that (a) the above dictionary failed to distinguish between proverbs and other prefabricated expressions and (b) nearly 67 percent out of the total number of the entries in the dictionary were found to be proverbs whereas around 33 percent of them turned out to be non-proverb items. Some lexicographic as well as research implications are also discussed at the end.
\end{abstract}

Keywords: LEXICOGRAPHY, NTC'S DICTIONARY, PROVERB, PROVERBIAL EXPRESSIONS, CLASSIFICATION SCHEME, FIXED EXPRESSIONS, IDIOM, CLICHÉ, ENTRY

Opsomming: Wat word beskou as 'n spreekwoord? Die geval van NTC's Dictionary of Proverbs and Clichés. 'n Spreekwoordeboek behoort sy naam gestand te doen deur die spesifieke, relevante formuleagtige inskrywings op te neem om die gevraagde inligting so vinnig en suksesvol moontlik op te spoor. Die teenstrydigheid tussen wat so ' $n$ woordeboek beweer hy opneem en wat hy inderdaad opneem mag spruit uit die feit dat daar nie aandag gegee word aan die moontlike grense tussen die vaste uitdrukkings, wat as riglyne in die leksikografie beskou kan word, nie. NTC's Dictionary of Proverbs and Clichés (Bertram 1996) is ondersoek as 'n voorbeeld van ' $n$ beskikbare spreekwoordeboek wat besonder nuttig vir niemoedertaalsprekers is. Hierdie ondersoek is gebaseer op die onderskeidings tussen vaste uitdrukkings wat aangebied word in Gramley en Pätzold (1992) en Simpson (1985). Daar is bevind dat (a) die bogenoemde woordeboek nagelaat het om te onderskei tussen spreekwoorde en ander vaste uitdrukkings en dat (b) byna 67 persent van die totale aantal inskrywings in die woordeboek spreekwoorde was teenoor ongeveer 33 persent van die items wat geblyk het nie spreekwoorde was nie. Ten slotte word sommige implikasies vir die leksikografie sowel as vir navorsing bespreek.

Sleutelwoorde: LEKSIKOGRAFIE, NTC SE WOORDEBOEK, SPREEKWOORD, SPREEKWOORDELIKE UITDRUKKINGS, KLASSIFIKASIESKEMA, VASTE UITDRUKKINGS, IDIOOM, CLICHÉ, INSKRYWING 


\section{Introduction}

Thanks to the advances in different fields of study, interdisciplinary approaches to addressing issues of research and practice are highlighted. The resultant contribution of different fields to one another seems to yield better output. From that perspective, lexicography is no exception. As the evidence, technology and computer sciences have contributed much to lexicography in the last decades. The result is that, with the aid of information and communication technology, we have gained within the last quarter of a century what might have been obtained for a century without its help. It has changed using the result of lexicography, i.e. using dictionaries, for native speakers and nonnatives learning a language. As Mark Warschauer (2005) observes, it has changed the context and how of language learning and, for that matter, has altered the context and how of using dictionaries as well; we look up the meaning of words in our mobiles nowadays, for instance.

Likewise, lexicography might also benefit from other fields such as linguistics, or more specifically discourse or corpus analysis, and so on. In this paper, we attempt to tackle a fine lexicographic issue from a linguistic point of view. Actually applying a corpus analyst's view to a proverb dictionary might shed some light on the dynamic field of lexicography with regard to proverb dictionaries.

International Journal of Lexicography, as an important outlet for the lexicographic community, has recently welcomed a collection of studies reaffirming the significance of efforts to further develop empirical study into dictionary use (IJL 2011). Lew (2011: 3) believes that "As experimental design, methods and techniques get more sophisticated, what we are getting in return is greater, finer, and more useful detail". All this indicates the point that interdisciplinary approaches are emphasized even in lexicography, thus inspiring further, even more innovative and revealing, efforts.

To start with, we must clarify our stance based on which we will consider a proverb dictionary, with probable direct and/or indirect lexicographic implications. Our approach, giving us that stance or foundation to report this study, emerges from the idiom principle of John Sinclair and is put forth much more in details by Gramley and Pätzold (1992). According to the idiom principle (Sinclair 1991: 110), "a language user has available to him or her a large number of semi-pre-constructed phrases that constitute single choices, even though they might appear to be analyzable into segments". On that basis, Gramley and Pätzold (1992), discussing words in combination, set out to propose a fixedexpression classification scheme and thus divide or classify such prefabricated phrases, called multi-word units, into well-established groups systematically so that any fixed expression might be included under one of the branches as neatly as possible. What makes the groups or units of fixed expressions distinct from one another pertains to a variety of stylistic, situational, formal, semantic, and syntactic aspects. 


\section{Classification of fixed expressions}

According to the classification scheme of fixed expressions proposed by Gramley and Pätzold (1992: 53), based on one criterion, fixed expressions are divided into two groups, one of which expresses meanings or speech acts, (i.e., acts performed by language) such as promises, warnings, requests, and the like, whereas the other group does not. Another criterion, they put forth, is whether or not 'the expression is equivalent to a whole sentence or free utterance'. Each of the two groups above is then classified into two levels or branches. In this division, the left branch is split into expressions that are utilized in 'set social situations' and those that are not, 'a pragmatic criterion'. The right branch, on the other hand, is subdivided by the semantic criterion of idiomaticity, i.e., a meaning that cannot be deduced from the meaning of the individual words (see Figure 1). The list below can be subdivided further to include other items but for the purposes of the current study we do not go further. The relationship between the items in Figure 1 will be clarified in the following pages. However, it is sufficient here to mention an exemplar expression for proverbs, idioms, collocations, and pragmatic idioms, respectively: (1) birds of a feather flock together, (2) how do you do, (3) red herring, and (4) meet demand.

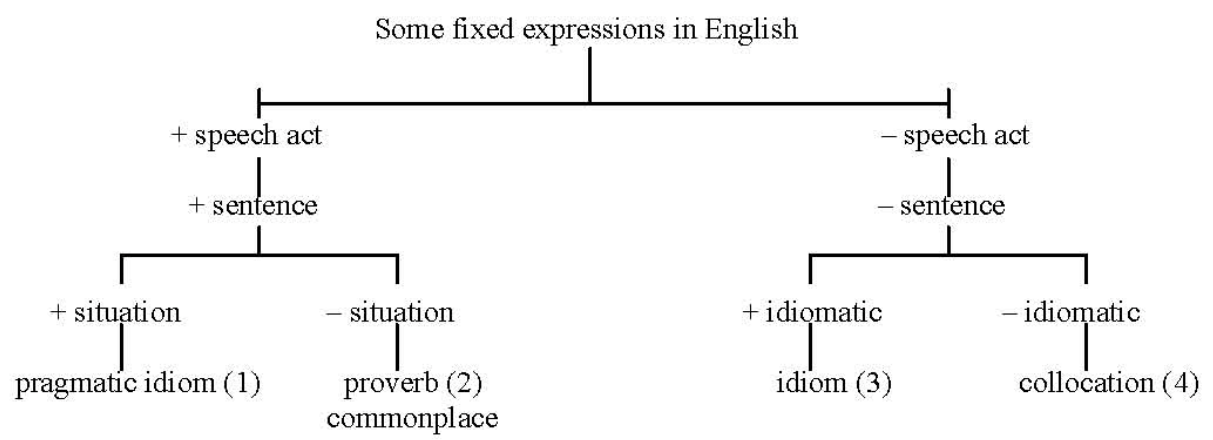

Figure 1: Fixed expressions in English (Gramley and Pätzold 1992: 54)

On the basis of the scheme above, we will only remain more focused on the distinction between a proverb and an idiom since the purpose of the present research is to investigate whether a sample of a compiled proverb dictionary meets these well established criteria or the lexicographers ignore the abovemade basics and consequently include items other than proverbs. The classification scheme above is a good and systematic device to distinguish the different kinds of fixed expressions. We also attempt to strengthen the criteria by adding some more points to the scheme above to make it better off in evaluating one specific dictionary as a sample of dictionaries on proverbs, namely, NTC's Dictionary of Proverbs and Clichés (Bertram 1996). 


\section{Clichés and fixed expressions}

What is worth mentioning with regard to the title and therefore the content of the dictionary is the term cliché. Howard (1984: 92) states that "clichés are routine or stereotypic forms that are found in many areas of life, for example, art, thought, behavior, visual images or urban architecture".

As to the linguistic description of clichés, Luelsdorff (1981) defines them as phrases, clauses and sentences which, owing to very frequent occurrence, have become hackneyed and trite. He divides the native clichés (English items) on the grammatical level into nominal, verbal, and sentence structures. Some language clichés are made up of single lexemes, for example, the journalistic items bombshell, brainchild, to harmonize, to orchestrate and scenario, but most consist of more than two items. Clichés, therefore, are applied to any formulaic item ranging from idioms to proverbs. That is, any fixed expression that is overused. The question that is posed here is whether it is appropriate to juxtapose the terms clichés with proverbs and then include other fixed expressions that are also considered clichés, such as idioms, in a dictionary especially compiled on proverbs.

The charge is that people, in using clichés, do not think when they use expressions such as acid test, psychological moment or leave no stone unturned (Gramley and Pätzold 1992).

Aside from this, there is another aspect to the issue of clichés as well. By using clichés one signals that one has acquired part of the socio-cultural competence of a given speech community (Luelsdorff 1981). Clichés help to create an in-group feeling of sympathy, solidarity and good will. Therefore, they fulfill an important social function (Gramley and Pätzold 1992). Stylistically speaking, published lists of clichés are mostly subjective (Brook 1981).

\section{Proverbs versus other fixed expressions}

To justify our position systematically, we have to clarify the issue of fixed expressions. Though in some cases it might be difficult, we try to distinguish the borders between the items in the classification scheme above. To that end, the items are to be contrasted further.

Proverbs are different from pragmatic idioms. The occurrence of pragmatic idioms is determined by a particular social situation. In fact, they need the context of situation to be understood correctly, for example, single or return is used at a railway ticket counter. Proverbs, however, do not function as such. They turn up everywhere. Proverbs sum up situations and give advice in short, terse phrases (Bertram 1996). Regarded as "the wit of one and the wisdom of many", the proverb is a terse and witty philosophical saying that conveys a lesson. It "couches conventional wisdom in a poetic capsule, making it esthetically pleasing and memorable" (Yankah 2001: 201).

As for the idioms, meaning is the decisive, if not the only, criterion. The 
word forms in an idiom do not constitute lexical units and do not make an isolable contribution to the meaning of the whole, while collocations consist of two word forms which are, at the same time, semantic constituents or lexical units. Idioms therefore show unitary meaning and their constituents are termed formatives by some linguists, according to Gramley and Pätzold (1992).

There are some means to recognize that an expression is an idiom, setting it off from the other kinds of prefabricated expressions. For one thing, the constituents in an idiom are not semantic constituents or lexical units; they are formatives. Relevant to that is 'recurrent semantic contrast' which is a test for a semantic constituent (Cruse 1986: 26-9). If hit and pail are contrasted with kick and bucket in the expression to kick the bucket, it becomes clear that kick the bucket is an idiom. The same goes for an adjectival idiom such as red herring: in red book and green book, red and green are in recurrent semantic contrast whereas in red herring and green herring they are not. Secondly, many idioms have two meanings, a literal and an idiomatic one. Consider kick the bucket or pull one's leg. In comprehending these idioms, only the context can give a clue as to which meaning is intended. We are dealing with an idiom if a literal meaning does not make sense in terms of the world as we know it. Thirdly, when an expression is formed in a way that is contrary to the syntactic rules of contemporary English, as in the definite articles in kick the bucket and fly off the handle, most probably it is an idiom. The definite article normally has the function of indicating that an item has already been mentioned. This condition is not fulfilled in the idioms cited (Dobrovol'skij and Piirainen: 2005). Finally, idioms can be phonologically irregular in that they have an unpredictable stress pattern (Strässler 1982).

Proverbs and commonplaces are free utterances or self-contained statements (Norrick 1985). Both can be equivalent to a complete sentence. However in the case of proverbs, shortened versions are quite common. Shortening and other changes - additions, variations, transpositions - do not necessarily affect the intelligibility of proverbs, apparently for they are well known (Akbarian 2010; Norrick 1985).

Proverbs show irregular syntax, for example, like father, like son which means 'a son will resemble his father'. Proverbs as well as commonplaces are concerned with general rather than specific meanings, which is why the past tense is not normally found with them. Many proverbs are metaphorical and may pose problems for understanding, while commonplaces are usually literal and easy to process (Norrick 1985: 70). Proverbs are well established, traditional, and recorded in many collections and dictionaries (Smith 1985). They contain 'a good dose of common sense, experience, wisdom and above all truth' (Mieder 1989: 15), 'have no known authors, and cannot be traced to specific sources', that is, they are folklore items (Gramley and Pätzold 1992: 77).

Sometimes, it is difficult to understand what some instances of proverbs really mean. For instance, 'a good husband makes a good wife' needs to be explained or at least thought about for a while before it makes sense. Still other 
proverbs preserve older forms of English words as well as older style and syntax. Some are difficult simply because they are used metaphorically. To exemplify, consider 'a stitch in time saves nine' that is never used in reference to sewing.

Proverbs as a class cannot be completely frozen (Gläser 1989, as cited in Gramley and Pätzold 1992). Some expressions mark proverbs, such as (as) they say, it is said, as the proverb goes that are called proverbial affixes by Norrik (1985). Moreover, variability is a characteristic trait of proverbs; they can be added to, transformed, and abbreviated. Transformations do not change proverbs out of all recognition such as it is while the iron is hot that it should be struck. Idioms would become meaningless or allow only a literal reading, if they are treated the same way.

Defining proverb as "a traditional saying which offers advice or presents a moral in a short and pithy manner", Simpson (1985: ix) in the introduction to the dictionary, The Concise Oxford Dictionary of Proverbs, states, "Paradoxically, many phrases which are called 'proverbial' are not proverbs as we now understand the term". He observes that this confusion dates from before the eighteenth century, when the term proverb also covered metaphorical phrases, similes, and descriptive epithets, and was used far more loosely than it is today. Nowadays, we normally expect a proverb to be cast in the form of a sentence.

However, according to Simpson (1985), some metaphorical phrases such as to cut off your nose to spite your face and to throw the baby out with the bathwater would be admitted as a proverb since they are rendered in the sentence form and contain some advice, wit, or universal truth, appearing as Don't cut off your nose to spite your face and Don't throw the baby out with the bathwater.

\section{Significance of the use of proverbs}

The proverb is grounded upon years of experience and close observation of life and natural phenomena, and through metaphorical language it may warn, advise, or reprimand by drawing attention to the moral or ethical consequences of human behavior. The proverb may advocate patience, cooperation, and perseverance, and repudiate greed and selfishness. A Turkish proverb says "He who does not listen to proverbs remains screaming for help"; according to Russians, "For the sake of a proverb, a peasant walks to Moscow"; and the Yoruba of Nigeria would say, "The man who knows proverbs reconciles difficulties". All this boils down to the fact that proverbs are prevailing in all the societies. Since they pertain to universal truth, they are welcomed as discourse ornaments. The proverb is a "lamp of the word" among the Arabs and an "ornament of speech" in Iran. The Igbo say that "proverbs are the palm oil with which words are eaten," implying that words are hard to swallow without a proverb lubricant. However, it takes considerable cultural sensitivity to grasp the full semantic nuances of the proverb in social interaction (Yankah 2001: 201-202).

According to Yankah (2001), the lessons often embedded in proverbs 
make them tools for moral education. Besides, the element of education in proverb use can be subsumed under the rhetorical function, that is, the proverb as a tool for persuasion in social interaction; the proverb user seeks to alter or reinforce the listener's conviction by referring him to timeless parallels within the proverb universe. By getting the addressee to agree with the moral precept in the proverb, the speaker thereby hopes to win him over. The rhetorical power of the proverb in part derives from its authoritative sources. Yankah (2001) mentions a few instances of this ascription: Among the Punjabi of India, proverbs are "the drum of God", and in Turkey proverbs from the prophets are said to have originated from the Holy Koran and Hadith holy traditions. In several African cultures, proverb authorship is ascribed to elders and ancestors.

\section{Typology of English proverb dictionaries}

Prędota (2003: 95-100) suggests that monolingual books of proverbs can be divided into three main categories:

1. Scientific: It has an historic character, including the complete treasure house of English-language proverbs. The Oxford Dictionary of English Proverbs (Oxford 1970) is an example.

2. Popular scientific: The Concise Oxford Dictionary of Proverbs (Oxford 1998) is an instance of this category, containing the current living core of the English treasury of proverbs.

3. Dictionaries destined for the teaching of foreign languages: This category has two characteristics, namely, (a) the dictionaries offer only a limited number of proverbs and (b) those selected generally belong to the famous and most frequent proverbs. Prędota presents English Proverbs (Stuttgart 1988) by Wolfgang Mieder as a good example for its practical lexicographic solutions. It includes 1200 proverbs with clarifying explanations to non-native speakers and dictionary articles kept to a minimum.

\section{The study}

There used to be and apparently there still is some confusion as to the distinction between the different types of fixed expressions; for example, some idioms are occasionally taken for proverbs (Simpson 1985). However, the classification scheme proposed above and the criteria established on the basis of the discussion above (Simpson 1985, Gramley and Pätzold 1992) contribute much to the issue at stake in that we have some well-established criteria to distinguish what is what among fixed or prefabricated expressions. This classification scheme can be suggested to lexicographers so that they might filter out what should and/or should not be included in a dictionary of proverbs before they tackle 
the issue of arranging the entries. Based on those criteria, this research intends to investigate a sample dictionary, namely, NTC's Dictionary of Proverbs and Clichés (Bertram 1996) in which the entries are defined and have realistic examples illustrating meaning, usage, and significance. The motivation for selecting this dictionary is that it is usually the only proverb dictionary available in libraries in Iran. The reason might be that it illustrates the meaning of the proverbs more clearly than any other proverb dictionaries and thus consulted most frequently by Iranian foreign language learners of English. Though the dictionary was published more than a decade ago, it can be regarded as one of the most up-to-date reliable sources since the proverbs contained do not change their nature over time. It is still reprinted as the same, without any revision. As a result, it could be recommended as a good source on proverbial expressions for everyone, especially for foreign language learners, until another revision or a better one comes out. In order to account for a possible lexicographic concern on proverb dictionaries, the following two specific questions guide the present research:

1. On the basis of the criteria above, does NTC's Dictionary of Proverbs and Clichés include only proverb entries or fail to distinguish between proverbs and other prefabricated expressions and include expressions other than the proverbial ones?

2. What percentage of the entries included in the sample dictionary investigated belongs to proverbs?

\section{Materials}

The material for the current study is NTC's Dictionary of Proverbs and Clichés (Bertram 1996). This dictionary is a selection of familiar expressions, some of which are also found in other major European languages. Below, the lexicographic microstructure of this dictionary is presented for the current research purposes:

- The entries are alphabetized by the first word in the expression, ignoring punctuation and hyphens.

- The dictionary gives clear definitions of the phrase and good examples of how it is used.

- It provides a literary source if one is known.

- Also, two brief dialogs accompany each expression, showing the typical way that the expression is used.

- Entry heads appear in boldface type, with expressions that are not entries, cited in italic font.

- Only one or two of the possible variants of a proverb are listed in this 
dictionary, printed in boldface type.

- Definitions and paraphrases are in roman type, with alternative definitions and paraphrases separated by semicolons.

- A definition or paraphrase may be followed by comments in parentheses that give extra information and list the common clichés derived from the entry heads.

- A Phrase-Finder Index is provided to permit easy locating of an entry head.

The dictionary includes 321 pages. There is an introduction of three pages. The entry heads of the dictionary run from page 1 to page 240 and the PhraseFinder Index from 241 to 321.

In this research, if a proverb has a variant idiom form originating from the head entry, i.e. proverb entry, the idiom is not regarded as violating the criteria of our investigation. It is excluded from the list of non-proverb items in this sample dictionary. Since that idiom is included and explained within a proverb entry, it is regarded as additional information for the entry, not a separate head entry in itself. Also, a non-proverb entry, such as an idiom, is not regarded as a separate entry if it is already explained as a variant or alternative of another idiom. For example, if the dictionary explains the idiom a drop in the bucket and mentions the idiom a drop in the ocean as the alternative form for the former and then offers the latter as another entry while cross-referencing to the former for the latter's meaning and exemplification, both are regarded as one entry. This holds true for the proverbs as well; the variant forms of proverbs are regarded as one single entry along with the relevant proverb unless they carry different meanings.

\section{Procedure}

To answer the questions posed above, NTC's Dictionary of Proverbs and Clichés (Bertram 1996) was considered carefully in accordance with the classification scheme offered above. All the entries were considered by the researcher and the number of proverbs and the non-proverb items were counted. The nonproverb items were separated from the proverbs (See Appendix).

\section{Results and discussion}

In accordance with the criteria put forth so far, the present research intends, firstly, to study whether NTC's Dictionary of Proverbs and Clichés (Bertram 1996) includes only proverb entries or fail to distinguish between proverbial and other prefabricated expressions and, as a result, includes expressions other than proverb entries, and secondly, what percentage of the entries included in 
the sample dictionary belongs to proverbs.

A careful investigation of the above dictionary showed that there were totally 982 entries in it. Out of the total number of entries, 656 entries belong to proverbs and the remaining 326 entries are not proverbs. In other words, $66.80 \%$ of the total number of the entries includes proverbs whereas $33.20 \%$ of the total number of the entries includes non-proverb items. Approximately, one third of the entries in the dictionary under study does not pertain to proverbs. Yet, we acknowledge the limited sample in our study. Therefore, it is not wise to generalize from our findings to other proverb dictionaries. However, at least this percentage of non-proverb items observed in this dictionary directly supports our position that the compilers of the current dictionary did not distinguish the boundaries between the prevailing fixed expressions such as idioms, proverbs, and the like.

At this stage, we will focus on the non-proverb entries (see Appendix) and try to see, in general, what structural category or pattern they mostly belong to, showing once again that these entries are totally different in kind from proverb entries:

1. Some non-proverb entries are made up of noun phrases expanded by prepositional phrases, e.g. a chip off the old block.

2. A few consist of (mixed) prepositional phrase, e.g. according to someone's lights or at sixes and sevens.

3. A large number of the entries include a structure like '(as) adjective as noun phrase', e.g. (as) drunk as a lord or (as) hard as nails.

4. Several of them are in the form of a dependent clause that is complete once the independent clause is provided by the language user, e.g. if (the) worst comes to (the) worst.

5. A greater number of the non-proverb entries in the Appendix consist of infinitive phrases (expanded by noun phrases or prepositional phrases, etc.), e.g. to fall between two stools, to give credit where credit is due, or to let the cat out of the bag.

6. The structure of a small number of the entries contains adjectives expanded by a prepositional phrase, e.g. crazy like a fox.

We have to acknowledge that there are instances of entries including other types of structures not mentioned above. However, it is important to note that some structures cited above are more common than others. For instance, structures 3 and 5 make up the majority of non-proverbs found in this dictionary. Further consideration of the arrangement of the entries in the dictionary reveals that there is a full stop (.) after the entries that are complete sentences. Indeed, the entries, followed by a full stop (.), are free and self-contained utterances. All of these entries are proverbs, not idioms (Akbarian 2010; Norrick 
1985); there is no full stop after any entry taken as an idiomatic expression in accordance with the scheme above. We take the entries without a full stop at the end of them to be non-proverbs for the reason that they cannot stand alone even if some of them include verbs. These entries, including verbs but not standing alone, are dependent clauses that need independent clauses. It would have helped the consultants of this dictionary further had the lexicographers marked the entries as such explicitly. The implication for lexicography is that the relevant items or entries comprising a particular type of dictionary should be exclusively included in their respective collections, and not in a collection of a different type of entries. As argued in this research, there are subtle differences between various types of fixed expressions, such as proverbs and idioms. However, if a particular type of expression or entry, e.g. an idiom, is associated with or emerges from proverbs, or for whatever reason, is to be included in a dictionary of proverbs, it should be recognized explicitly as an idiomatic expression. In this manner, users' attention will be explicitly drawn to the entries and the need for a more consistent organization of the entries emerging from the analysis of the dictionaries will be highlighted (Szczepaniak and Lew 2011), as suggested in this paper. It could have double lexicographic and pedagogical effect for the consultants of this type of dictionaries who are mainly language learners; From a lexicographic perspective, the structure of the dictionary would contain clear clues as to the contents and, from a pedagogical perspective, the consultants of such dictionaries will get cognizant of both of these expressions and their distinctive boundaries. The following is suggested as an example of how the items should be arranged and marked:

(As) busy as a cat on a hot tin roof (idiom) Full of lively activity; very busy. $\square$ I'm afraid I can't go to lunch with you on Saturday; I'll be busy as a cat on a hot tin roof, between working overtime and the two parties I have to go to.

Practice makes perfect. (proverb) Doing something over and over again is the only way to learn to do it well. $\square$ JILL: I'm not going to try to play the piano anymore. I always make so many mistakes. JANE: Don't give up. Practice makes perfect.

In order to support the findings of the present study, we further attempted to investigate other dictionaries. Since most of the non-proverb items observed in the dictionary under study were idioms, we investigated NTC's American Idioms Dictionary, compiled by Richards A. Spears (2000), to see whether the nonproverb items found in NTC's Dictionary of Proverbs and Clichés (Bertram 1996) had been included in NTC's American Idioms Dictionary as idiom entries. It is worth emphasizing here that the two dictionaries were published by the same publisher, that is, NTC Publishing Group.

For the purpose of our study, we randomly investigated every tenth entry of the non-proverb entries in the Appendix. We randomly started with number 3. Therefore, entries numbered $3,13,23,33,43,53$, and so on in our list were 
considered (see Appendix). This amounted to one tenth of the total non-proverb items in Appendix. With the non-proverb items numbering 326, this amounted to 33 of the non-proverb items, out of which 19 items were observed in NTC's American Idioms Dictionary, compiled by Richards A. Spears (2000) and the remaining 14 were not observed in that dictionary. So the comparison of our results with the dictionary on idioms supported our findings; $57.58 \%$ of the non-proverb entries we found in NTC's Dictionary of Proverbs and Clichés were definitely idioms whereas the remaining $42.42 \%$ of the randomly selected number of non-proverb items were not observed in NTC's American Idioms Dictionary. The remaining 14, though unobserved in the above idiom dictionary, are mostly idioms based on the criteria offered in this research. This evidence supported the finding of the current research in that the lexicographers had not heeded the boundaries between the fixed expressions and especially those of idioms and proverbs, thus indiscriminately compiling both proverbs and idioms in a single dictionary of proverbs.

This finding leads one to assume that the other dictionaries compiled on the other kinds of formulaic or prefabricated expressions, such as idioms, clichés, and so on, might be suffering from a similar indiscriminate compilation of various entries of prefabricated expressions or be prone to the confusion as to the distinctions between the fixed expressions as the dictionary investigated in this study. On that basis, despite the limited scope of the study, the researcher assumes that the finding might be of some interest to the lexicographers. However, further research is needed to shed more light on the issue.

What is also worth mentioning here is that clichés are applied to any formulaic item ranging from idioms to proverbs, that is, any fixed expression that is overused. People, in fact, do not think when they use clichés. The question that is posed in this regard is whether it is appropriate to juxtapose the terms clichés with proverbs as the title of a dictionary and then include other fixed expressions that are also considered clichés, such as idioms, in a dictionary especially compiled on proverbs. Clichés and proverbs are different categories in themselves and should be considered or discussed from a different perspective. To put it proverbially, it is highly appropriate to avoid comparing oranges and apples.

Given that the needs of dictionary users are so varied, it is recommended that dictionaries should be compiled with the users' needs foremost in mind, as most experts now agree. However, "very few studies actually address this point directly and in sufficient detail (Lew 2011: 1). To take fuller advantage of the offerings of modern lexicography, awareness-raising should be carried out in learners with regard to what the boundaries among the fixed expressions are. Not mixing the proverbs and idioms in a single dictionary can be recommended as an indirect way to do it.

Implementing the suggestions set forth in this paper by the lexicographers will contribute to the primary function of dictionaries, in our case a good dictionary of proverbs; the primary function "is often assumed to be that of pro- 
viding immediate assistance in comprehension and production problems (Verlinde, Leroyer, and Binon: 2010). And what makes a dictionary good? In answer to this question, Bergenholtz and Gouws (2010: 119) would say very simply: "It is a dictionary that quickly and securely gives the correct answer to a question posed by the user when consulting a dictionary."

To conclude, our investigation has produced evidence, pointing to the need to reconsider the collection of fixed expressions with regard to the general linguistic boundaries between fixed expressions as illustrated in the scheme put forth by Gramley and Pätzold (1992) and strengthened further in this paper. Our results would lead us to agree with Atkins and Rundell (2008: 4) who observe that "There is an enormous body of linguistic theory which has the potential to help lexicographers to do their jobs more effectively and with greater confidence." Therefore, through interaction with other independent fields of study, e.g. linguistics and technology, lexicography as an independent and dynamic field would ascertain the nature of future dictionaries and improve the access to the data, especially in dictionaries on any type of fixed expressions. The users will securely be guided to the specific place where the relevant data is accommodated so as to retrieve the required information. As Bergenholtz and Gouws (2010: 125) state, "Successful retrieval of information has a well-designed access process as a prerequisite." The scheme above might be of some help.

\section{References}

Akbarian, I. 2010. A Spice of Classroom: Incorporating Proverbial Expressions in EFL Classes. Journal of Asia TEFL 7(1): 221-238.

Atkins, B.T.S. and M. Rundell. 2008. The Oxford Guide to Practical Lexicography. Oxford/ New York: Oxford University Press.

Bergenholtz, H. and R. Gouws. 2010. A New Perspective on the Access Process. Hermes, Journal of Language and Communication Studies 44: 103-127.

Bertram, A. 1996. NTC's Dictionary of Proverbs and Clichés. Lincolnwood, Illinois: NTC Publishing Group.

Brook, G.L. 1981. Words in Everyday Life. London: Macmillan.

Cruse, D. 1986. Lexical Semantics. Cambridge: Cambridge University Press.

Dobrovol'skij, D. and E. Piirainen. 2005. Figurative Language: Cross-cultural and Cross-linguistic Perspectives. Amsterdam: Elsevier.

Gramley, S. and K.M. Pätzold. 1992. A Survey of Modern English. London: Routledge.

Howard, P. 1984. Cliché. The State of the Language: 87-99. London: Hamish Hamilton.

Lew, R. 2011. Studies in Dictionary Use: Recent Developments. International Journal of Lexicography 24(1): $1-4$.

Luelsdorff, P. 1981. What is a Cliché? Trier: LAUT Papers, Series A, no. 85.

Mieder, W. 1988. English Proverbs. Stuttgart: Philipp Reclam.

Mieder, W. 1989. American Proverbs: A Study of Texts and Contexts. Bern: Peter Lang. 
Norrick, N. 1985. How Proverbs Mean. Berlin/New York: Mouton.

Prędota, S. 2003. Dictionaries of Proverbs. Van Sterkenburg, P. (Ed.). 2003. A Practical Guide to Lexicography: 94-101. Amsterdam: John Benjamins.

Simpson, J. 1985. The Concise Oxford Dictionary of Proverbs. New York: Oxford University Press.

Sinclair, J.M. 1991. Corpus, Concordance, Collocation. Oxford: Oxford University Press.

Smith, G. 1985. The English Companion. Harmondsworth: Penguin.

Spears, R.A. 2000. NTC's American Idioms Dictionary. Lincolnwood, Illinois: NTC Publishing Group.

Strässler, J. 1982. Idioms in English: A Pragmatic Analysis. Tübingen: Gunter Narr.

Szczepaniak, R. and Lew, R. 2011. The Role of Imagery in Dictionaries of Idioms. Applied Linguistics 32(3): 323-347.

Warschauer, M. 2005. Forword. Arnó Macià, E., A. Soler Cervera and C. Rueda Ramos (Eds.). 2005. Information Technology in Languages for Specific Purposes: Issues and Prospects: xiii-xv. New York: Springer.

Verlinde, S., P. Leroyer and J. Binon. 2010. Search and You Will Find. From Stand-alone Lexicographic Tools to User Driven Task and Problem-oriented Multifunctional Leximats. International Journal of Lexicography 23(1): 1-17.

Yankah, K. 2001. Proverb. Duranti, A. (Ed.). 2001. Key Terms in Language and Culture: 201-203. Malden, MA: Blackwell and American Anthropology Association. 


\section{Appendix}

1. A blessing in disguise (p. 2)

2. A bolt from the blue (p. 2)

3. A castle in Spain (p. 3)

4. A chip off the old block (p. 4)

5. A drop in the bucket/a drop in the ocean (p. 5)

6. A fine kettle of fish (p. 5)

7. A fish out of water (p. 5)

8. A fool's paradise (p. 6)

9. A penny for your thoughts (p. 11)

10. A square peg in a round hole/ trying to fit a square peg into a round hole (p. 13)

11. A wolf in sheep's clothing (p. 15)

12. According to Hoyle (p. 17)

13. According to someone's lights (p. 18)

14. Add insult to injury (p. 18)

15. (All) other things being equal (p. 19)

16. (As) bald as a coot/(As) bald as a baby's backside (p. 24)

17. (As) black as a sweep (p. 24)

18. (As) black as coal/(As) black as pitch (p. 24)

19. (As) blind as a bat (p. 25)

20. (As) bold as brass (p. 25)

21. (As) bright as a button (p. 25)

22. (As) bright as a new pin (p. 25)

23. (As) busy as a beaver (p. 25)

24. (As) busy as a bee/a busy bee (p. 25)

25. (As) busy as a cat on a hot tin roof (p. 25)

26. (As) clean as a hound's tooth (p. 26)

27. (As) clean as a whistle (p. 26)

28. (As) cold as a witch's tit (p. 26)

29. (As) cold as marble (p. 26)

30. (As) common as dirt (p. 26)

31. (As) cool as a cucumber (p. 26)

32. (As) crazy as a loon (p. 27)

33. (As) dead as a doornail/Deader than a doornail (p. 27)

34. (As) dead as the dodo (p. 27)

35. (As) deaf as a post (p. 27)

36. (As) drunk as a lord (p. 27)

37. (As) drunk as a skunk (p. 27)

38. (As) dry as a bone/Bone-dry (p. 27)
39. (As) dull- as ditchwater/(As) dull as dishwater (p. 28)

40. (As) easy as A, B, C (p. 28)

41. (As) fat as a pig (p. 28)

42. (As) fit as a fiddle (p. 28)

43. (As) flat as a board (p. 28)

44. (As) flat as a pancake (p. 28)

45. (As) free as (the) air (p. 28)

46. (As) gaudy as a butterfly (p. 29)

47. (As) gentle as a lamb (p. 29)

48. (As) good as gold (p. 29)

49. (As) graceful as a swan (p. 29)

50. (As) gruff as a bear (p. 29)

51. (As) happy as a clam (p. 29)

52. (As) happy as a lark (p. 29)

53. (As) hard as nails (p. 29)

54. (As) hoarse as a crow (p. 30)

55. (As) hot as fire (p. 30)

56. (As) hungry as a hunter (p. 30)

57. (As) keen as mustard (p. 30)

58. (As) light as a feather/(As) light as air (p. 30)

59. (As) luck would have it (p. 30)

60. (As) mad as a hatter (p. 30)

61. (As) mad as a March hare (p. 31)

62. (As) meek as a lamb (p. 31)

63. (As) merry as a cricket (p. 31)

64. (As) naked as a jaybird (p. 31)

65. (As) neat as a pin (p. 31)

66. (As) nutty as a fruitcake/Nuttier than a fruitcake (p. 31)

67. (As) old as the hills (p. 31)

68. (As) pale as a ghost (p. 32)

69. (As) pale as death (p. 32)

70. (As) patient as job (p. 32)

71. (As) plain as a pikestaff (p. 32)

72. (As) plain as the nose on one's face (p. 32)

73. (As) pleased as Punch (p. 32)

74. (As) poor as a church-mouse (p. 33)

75. (As) proud as a peacock/(As) vain as a peacock (p. 33)

76. (As) pure as the driven snow (p. 33)

77. (As) queer as a three-dollar bill (p. 33) 
78. (As) quick as lightning/ swift as lightning (p. 33)

79. (As) quiet as a mouse (p. 33)

80. (As) red as a cherry (p. 33)

81. (As) red as a poppy (p. 34)

82. (As) red as a rose/Rose-red (p. 34)

83. (As) red as a ruby/Ruby-red (p. 34)

84. (As) red as blood/Blood-red (p. 34)

85. (As) regular as clockwork (p. 34)

86. (As) right as a trivet (p. 34)

87. (As) right as rain (p. 34)

88. (As) scarce as hen's teeth/Scarcer than hen's teeth (p. 35)

89. (As) sharp as a razor/Razor-sharp (p. 35)

90. (As) sharp as a tack (p. 35)

91. (As) silent as the dead/(As) silent as the grave (p. 35)

92. (As) silly as a goose/A goose (p. 35)

93. (As) slippery as an eel (p. 35)

94. (As) slow as molasses in January/ Slower than molasses in January (p. 36)

95. (As) smooth as glass (p. 36)

96. (As) snug as a bug in a rug (p. 36)

97. (As) sober as a judge/(As) grave as a judge (p. 36)

98. (As) soft as down (p. 36)

99. (As) soft as velvet/Velvety-soft (p. 36)

100. (As) solid as a rock/Rock-solid (p. 36)

101. (As) sound as a dollar (p. 37)

102. (As) sour as vinegar (p. 37)

103. (As) steady as a rock/Rock-steady (p. 37)

104. (As) stiff as a poker (p. 37)

105. (As) still as death (p. 37)

106. (As) straight as an arrow (p. 37)

107. (As) strong as a horse/(As) strong as an ox (p. 37)

108. (As) strong as a lion (p. 38)

109. (As) stubborn as a mule/(As) obstinate as a mule (p. 38)

110. (As) sure as death (p. 38)

111. (As) sweet as honey/Sweeter than honey (p. 38)

112. (As) sweet as sugar (p. 38)
113. (As) swift as an arrow (p. 38)

114. (As) swift as the wind/Like the wind (p. 38)

115. (As) swift as thought (p. 39)

116. (As) thick as thieves (p. 39)

117. (As) tight as a drum (p. 39)

118. (As) tight as a tick (p. 39)

119. (As) tough as a (shoe) leather (p. 39)

120. (As) true as steel (p. 39)

121. (As) ugly as a toad (p. 39)

122. (As) ugly as $\sin$ (p. 40)

123. (As) warm as toast (p. 40)

124. (As) weak as a baby (p. 40)

125. (As) white as a sheet (p. 40)

126. (As) white as snow/Snow-white (p. 40)

127. (As) wise as Solomon/the wisdom of Solomon (p. 40)

128. At sixes and sevens (p. 41)

129. At the drop of hat (p. 41)

130. At this point in time (p. 42)

131. Babe in the woods (p. 43)

132. Back to the salt mine (p. 43)

133. Bark up the wrong tree (p. 44)

134. Batten down the hatches (p. 44)

135. Be one's own man/Be one's own master (p. 44)

136. Be one's own worst enemy (p. 45)

137. Beard the lion in his den/Beard someone in his den (p. 45)

138. Before you can say Jack Robinson (p. 46)

139. Better left unsaid (p. 47)

140. Between the devil and the deep blue sea/Between a rock and a hard place (p. 48)

141. Between you and me and the bedpost/Between you and me and these four walls (p. 48)

142. Beyond a shadow of a doubt (p. 48)

143. Born on the wrong side of the blanket (p. 50)

144. Born with a silver spoon in one's mouth (p. 51)

145. Bright-eyed and bushy-tailed (p. 51)

146. Bring home the bacon (p. 52)

147. Build castles in the air (p. 52) 
148. Burn one's bridges (behind one) (p. 52)

149. Burn the candle at both ends (p. 53)

150. Burn the midnight oil (p. 53)

151. Bury the hatchet (p. 53)

152. Butter wouldn't melt (in someone's mouth) (p. 53)

153. Buy a pig in a poke (p. 54)

154. By the sweat of one's brow (p. 54)

155. By word of mouth (p. 54)

156. Call a spade a spade (p. 55)

157. Cannot call one's soul one's own (p. 56)

158. Cannot hit the broad side of a barn (p. 56)

159. Cannot see the wood for the trees (p. 56)

160. Can't hold a candle to someone (p. 56)

161. Carry coals to Newcastle (p. 56)

162. Cast the first stone (p. 57)

163. Catch-as-catch-can (p. 57)

164. Close enough for government work (p. 59)

165. Come on like gangbusters (p. 60)

166. Come out smelling like a rose (p. 60)

167. Come up roses (p. 60)

168. Come within an inch of something/Come within a hair's breadth of something (p. 60)

169. Conspicuous by one's absence (p. 61)

170. Cool, calm, and collected (p. 62)

171. Cost a pretty penny (p. 62)

172. Crazy like a fox (p. 63)

173. Cry all the way to the bank (p. 64)

174. Damn someone with faint praise (p. 65)

175. Doesn't have the sense God gave geese (p. 69)

176. Drink like a fish (p. 73)

177. Dry as dust (p. 73)

178. Duck soup (p. 73)

179. Eat someone out of house and home (p. 76)
180. Enough to keep body and soul together (p. 77)

181. Escape by the skin of one's teeth/ By the skin of one's teeth (p. 77)

182. Fall between two stools (p. 82)

183. Far from the madding crowd (p. 83)

184. Feel something in one's bones (p. 83)

185. Fiddle while Rome burns (p. 84)

186. Fight fire with fire (p. 84)

187. First see the light of day (p. 86)

188. Get down to brass tracks (p. 91)

189. Get it on the ground floor (p. 91)

190. Get it straight from the horse's mouth (p. 91)

191. Get up on the wrong side of the bed (p. 92)

192. Give credit where credit is due (p. 92)

193. Give someone a dose of his own medicine (p. 92)

194. Give someone the benefit of the doubt (p. 93)

195. Give the shirt off one's back (p. 94)

196. Go from bad to worse (p. 94)

197. Go like the wind (p. 94)

198. Go over/through something with a fine-tooth comb (p. 94)

199. Going to hell in a hand-basket (p. 94)

200. Good riddance to bad rubbish! (p. 96)

201. Grist for the mill/someone's mill (p. 97)

202. (Has the) cat got your tongue? (p. 100)

203. Haul/Rake someone over the coals (p. 100)

204. Have a bee in one's bonnet (p. 100)

205. Have a bone to pick (with someone) (p. 100)

206. Have a chip on one's shoulder (p. 101)

207. Have a finger in every pie (p. 101)

208. Have an ace up one's sleeve (p. 101)

209. Have an axe to grind (p. 101) 
210. Have bats in the belfry/Batty crazy/Bats (p. 101)

211. Have better (or other) fish to fry (p. 102)

212. Have one foot in the grave (p. 102)

213. Have second thoughts (p. 102)

214. Have the courage of one's convictions (p. 102)

215. Have too many irons in the fire (p. 102)

216. Have too much of a good thing (p. 103)

217. Here's mud in your eye (p. 109)

218. Hide one's light under a bushel (p. 109)

219. Hit the nail on the head (p. 109)

220. Hoist with one's own petard (p. 110)

221. I would not touch it with a tenfoot pole (p. 113)

222. If the truth were known (p. 116)

223. If (the) worst comes to (the) worst (p. 116)

224. In (at) one ear and out (of) the other (p. 120)

225. In this day and age (p. 121)

226. It is (all) Greek to me (p. 126)

227. It's six of one, half a dozen of another (p. 128)

228. Keep a stiff upper lip (p. 130)

229. Keep one's nose to the grindstone (p. 131)

230. Keep up with the Joneses (p. 131)

231. Kill two birds with one stone (p. 132)

232. Know which side one's bread is buttered on (p. 132)

233. Laugh all the way to the bank (p. 134)

234. Laugh out of the other side of one's mouth (p. 134)

235. Leave no stone upturned (p. 135)

236. Let the cat out of the bag (p. 136)

237. Life is just a bowl of cherries (p. 137)

238. Like a bat out of hell (p. 138)

239. Like a bull in a china shop (p. 138)

240. Like a bump on a $\log$ (p. 139)

241. Like death warmed over (p. 139)

242. Like greased lightning (p. 139)
243. Like two peas in a pod (p. 140)

244. Look for a needle in a haystack (p. 142)

245. Make a clean breast of it (p. 144)

246. Make a long story short (p. 144)

247. Make a mountain out of a molehill (p. 144)

248. Make a virtue of necessity (p. 145)

249. Make one turn (over) in one's grave (p. 145)

250. Make the best of a bad job (p. 146)

251. Make one's p's and q's (p. 149)

252. Mind your own business (p. 149)

253. Money burns a hole in someone's pocket (p. 150)

254. Much ado about nothing (p. 152)

255. Neither rhyme nor reason (p. 154)

256. Never a dull moment (p. 154)

257. Nineteen to the dozen (p. 157)

258. No sooner said than done (p. 158)

259. Not able to get something for love or money (p. 158)

260. Not able to make head or tail of something (p. 158)

261. Not enough room to swing a cat (p. 158)

262. Not one's cup of tea (p. 159)

263. Not to know someone from Adam (p. 159)

264. Not to let the grass grow under one's feet (p. 159)

265. Not worth a hill of beans (p. 159)

266. Not worth the paper it is written on (p. 160)

267. Nothing to boast about (p. 161)

268. Nothing to write home about (p. 161)

269. Once in a blue moon (p. 163)

270. One's heart is in one's mouth/With one's heart in one's mouth/Have one's heart in one's mouth (p. 166)

271. Paddle one's own canoe (p. 169)

272. Pay the piper (p. 169)

273. Pay through the nose (p. 169)

274. Pour oil on troubled waters (p. 171)

275. Pull oneself up by the bootstraps/ Pull oneself up by one's bootstraps (p. 173) 
276. Pull the wool over someone's eyes. (p. 173)

277. Put one's best foot forward (p. 173)

278. Put one's foot down (p. 174)

279. Put one's foot in it (p. 174)

280. Put one's shoulder to the wheel (p. 174)

281. Put something on the line (p. 174)

282. Put that in your pipe and smoke it (p. 174)

283. Put your money where your mouth is (p. 175)

284. Rain cats and dogs (p. 176)

285. Read between the lines (p. 176)

286. Read someone like a(n open) book (p. 177)

287. Ring down the curtain (p. 177)

288. Rob Peter to pay Paul (p. 178)

289. Save for a rainy day (p. 179)

290. Seize the bull by the horns/Take the bull by the horns (p. 180)

291. Separate the men from the boys (p. 181)

292. Separate the sheep from the goats (p. 181)

293. Separate the wheat from the chaff (p. 181)

294. Set a thief to catch a thief (p. 182)

295. Share and share alike (p. 182)

296. Ships that pass in the night (p. 182)

297. Sleep like a $\log$ (p. 184)

298. Sleep like a top (p. 184)

299. Slow but sure/Slowly but surely (p. 185)

300. Someone cannot see beyond the end of his nose (p. 185)

301. Someone is not out of the woods yet (p. 185)

302. Someone puts his pants on one leg at a time (p. 186)
303. Someone will get his (or hers) (p. 186)

304. Stand the test of time (p. 187)

305. Strain at gnats and swallow camels (p. 188)

306. Take the bit between one's teeth (p. 190)

307. Take the bitter with the sweet (p. 190)

308. Take the rough with the smooth (p. 191)

309. Take the wind out of someone's sails (p. 191)

310. Tar someone with the same brush (p. 191)

311. The biggest frog/toad in the puddle (p. 194)

312. The devil to pay/Someone has the devil to pay/There will be the devil to pay (p. 198)

313. The fat is in the fire (p. 200)

314. The left hand doesn't know what the right hand is doing (p. 203)

315. The less said (about something), the better (p. 203)

316. The lesser of two evils (p. 203)

317. The long and the short of it (p. 203)

318. The last straw/The straw that broke the camel's back (p. 208)

319. The time is ripe (p. 208)

320. The whole ball of wax (p. 210)

321. Tied to one's mother's apron strings/ Cut the apron strings (p. 218)

322. Turn back the clock (p. 222)

323. Water over the dam/Water under the bridge (p. 226)

324. What in (the) Sam Hill (p. 227)

325. Wild horses couldn't drag someone away from something (p. 233)

326. Your guess is as good as mine (p. 239) 